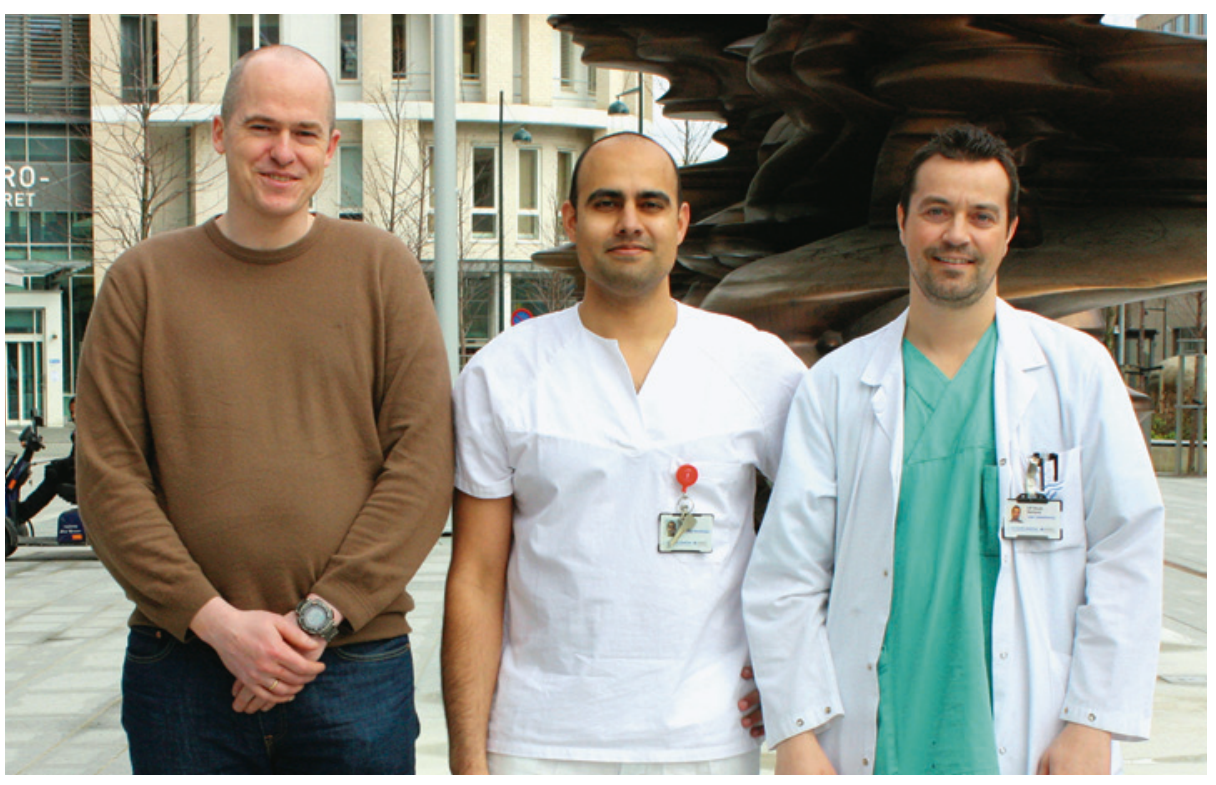

Fra venstre: Øyvind Salvesen, som er medisinsk statistiker, Sasha Gulati og Ulf Skule Nerland. Foto: John Barnes

\section{Mikrokirurgi eller laminektomi ved spinal stenose?}

Mikrokirurgisk dekompresjon og laminektomi ved lumbal spinal stenose gir like gode resultater ett år etter operasjon, viser en ny norsk studie.

Lumbal spinal stenose er den vanligste årsaken til operasjon i ryggen hos pasienter over 60 år. Prinsippet for kirurgi er å skape plass for nervene ved at man fjerner omkringliggende vev og påleiringer $i$ håp om at smertene skal avta. I økende grad benyttes minimalt invasive metoder. Fordelene med slike metoder er mindre sårsmerter og at pasientene kan mobiliseres og utskrives fra sykehus tidligere.

De nye operasjonsmetodene er imidlertid blitt tatt i bruk uten tilstrekkelig dokumentasjon for at resultatene er like gode som ved den tradisjonelle og mer omfattende operasjonsmetoden laminektomi. I en studie som nylig er publisert i tidsskriftet $B M J$, har man sammenliknet mikrokirurgisk dekompresjon og laminektomi (1).

Studien omfattet 885 pasienter, operert ved 34 norske avdelinger i ortopedi eller nevrokirurgi i perioden 2006-11. Ett år etter operasjonen opplevde pasientene operert med mikrokirurgisk dekompresjon samme bedring som pasientene operert med laminektomi. Resultatene var gode i begge gruppene med stor bedring av ryggspesifikk funksjon, i dagliglivets aktiviteter og helserelatert livskvalitet. Det var ingen forskjeller i komplikasjoner mellom de to operasjonsmetodene, og alvorlige komplikasjoner var svært få.

- Denne studien er et eksempel på såkalt sammenliknende effektforskning, og en av styrkene er at den er blitt gjennomført under forhold som mest mulig etterlikner vanlig klinisk praksis i en stor pasientpopulasjon, sier overlege og førsteamanuensis Sasha Gulati, som er studiens sisteforfatter. - Sammenliknende effektforskning har fått økende oppmerksomhet de senere år, og i Norge har vi en rekke medisinske kvalitetsregistre som er svært godt egnet for denne typen forskning, sier Gulati.

\section{Billig og bra}

Studien utgår fra en forskningsgruppe ved Nevrokirurgisk avdeling på St. Olavs hospital i Trondheim med Sasha Gulati som prosjektleder. Studien er en del av doktorgradsarbeidet til Ulf Skule Nerland, som er lege i spesialisering i nevrokirurgi. I studien benyttet de data fra Nasjonalt kvalitetsregister for ryggkirurgi, som er underlagt Universitetssykehuset Nord-Norge, og studien ble i sin helhet finansiert av en bevilgning på kr 150000 fra Legeforeningens Fond for kvalitet og pasientsikkerhet.

\section{Lise Mørkved Helsingen}

Tidsskriftet

\section{Litteratur}

1. Nerland US, Jakola AS, Solheim 0 et al. Minimally invasive decompression versus open laminectomy for central stenosis of the lumbar spine: pragmatic comparative effectiveness study. BMJ 2015; 350: h1603.

Publisert først på nett.
Ordforklaringer

Spinal stenose: Innsnevring av ryggmargs kanalen. Innsnevringen kan trykke direkte på ryggmargen eller på nerverøttene som forgreiner seg ut fra ryggmargen.

Mikrokirurgisk dekompresjon: Minimal invasiv operasjonsmetode for lumbal spinal stenose. Man lager kun et lite hudsnitt og benytter operasjonsmikroskop. Midtlinjestrukturer bevares og muskeltraumet blir mindre.

Laminektomi: Tradisjonell operasjonsmetode for lumbal spinal stenose med fjerning av én eller flere virvelbuer i ryggraden. 